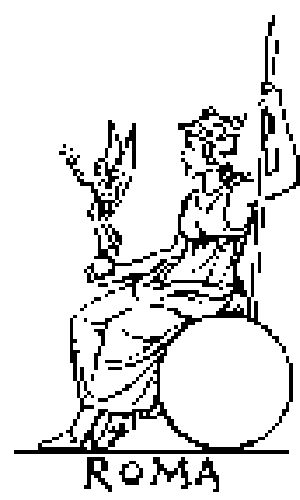

Roman Silver Coins Found at Corstopitum

Author(s): H. H. E. Craster

Source: The Journal of Roman Studies, Vol. 5 (1915), pp. 173-190

Published by: Society for the Promotion of Roman Studies

Stable URL: http://www.jstor.org/stable/296305

Accessed: 08/05/2014 23:10

Your use of the JSTOR archive indicates your acceptance of the Terms \& Conditions of Use, available at http://www.jstor.org/page/info/about/policies/terms.jsp

JSTOR is a not-for-profit service that helps scholars, researchers, and students discover, use, and build upon a wide range of content in a trusted digital archive. We use information technology and tools to increase productivity and facilitate new forms of scholarship. For more information about JSTOR, please contact support@ jstor.org. 


\section{ROMAN SILVER COINS FOUND AT CORSTOPITUM.}

By H. H. E. CRASTER.

No apology need be made for setting out in full a list of the silver coins found in the course of seven years' digging (1906 to 1912) on the Romano-British site of Corstopitum near Corbridge-on-Tyne, three miles south of Hadrian's Wall, in Northumberland. So much attention has been paid to coin-hoards, so little to the general character of coins found on Roman sites, that we are in danger of neglecting half the evidence which excavation is able to furnish. For hoards and general coin-finds naturally differ in their character. A hoard furnishes evidence as to what coins were in circulation together, or were in circulation during a limited if indefinite period, namely, the period of hoarding. Lost unhoarded coins-lost because they were not hoarded-tell a different tale. Whereas in hoards the latest years are, normally, most plentifully represented, lost coins may be taken to bear a constant proportion to the total amount of money circulating throughout the period of occupation. They furnish better historical evidence in regard to a site, for, whereas the period of occupation can usually be settled by other data, the period of hoarding can only be arrived at from the evidence of the hoard itself taken in conjunction with other hoards of different date: the terminus ad quem of a hoard can be easily ascertained, but the terminus a quo is bound to remain indefinite. Hoards are usually composed of coins of a single denomination, but in unhoarded coin all classes of currency are, or may be, equally represented; the personal factor is excluded, and different denominations are found in much the same proportion to that in which they circulated.

Certain misconceptions in regard to the historical value of unhoarded coin require to be removed. In the first place, there is the common idea that the sole deduction to be made from coin-finds is the period of occupation of a particular site. Secondly, there is a more insidious opinion that the number of coins of particular periods found on a site varies simply with the extent of the population. A real truth underlies the theory thus crudely stated, but the conclusion to be derived is the degree of wealth, and not the mere size, of a settlement. Large coin-finds, especially if they include gold and silver, imply prosperity or trading activity; a paucity of coins, on the other hand, argues impoverishment or a primitive condition in which trade is conducted by barter. Military and civil communities may be expected to differ in this as in other respects, though the degree of difference has still to be determined by results. The evidence on which conclusions might be based is as yet almost wholly wanting. It has to be extensive, in order to eliminate the element of chance. Coins have to be classified not by names but by actual dates: for 
instance, coins of Domitian as Caesar require to be reckoned as currency of Vespasian; similarly, coins bearing the head of Marcus Aurelius as Caesar must be assigned to the era of Antoninus Pius. Attention has more especially to be directed to the different species of currency, and each species must be taken by itself. Finally, allowance must be made for the length of time during which particular classes of coin remained in circulation.

With these principles in mind, we may turn to an examination of the silver coins found at Corstopitum. The bronze coins found on the site are too numerous and of too little individual interest to be set out here in detail, and full catalogues of them have been printed in the official reports of the Corbridge excavations. ${ }^{1}$ The totals of the silver coins are given below: totals of the bronze money of the same period are set out in the course of the subsequent pages, in which an attempt is made to draw certain inferences from the statistics here recorded.

SYNOPSIS OF ROMAN SILVER COINS FOUND AT CORSTOPITUM.

\begin{tabular}{|c|c|c|c|c|c|}
\hline \multicolumn{2}{|c|}{ I. Denarii. } & Caracalla & & . & 17 \\
\hline Republic & 4 & Plautilla & .. & .. & 2 \\
\hline Mark Antony .. & 23 & Geta $\quad$. & .. & .. & 6 \\
\hline Augustus & I & Elagabalus & .. & .. & 7 \\
\hline Galba .. & 3 & Julia Paula & & $\therefore$ & I \\
\hline Vitellius & 4 & Julia Aquilia & & .. & I \\
\hline Vespasian & $3 \mathrm{I}$ & Julia Soaemias & & $\cdots$ & 2. \\
\hline Titus $\ldots$ & 7 & Julia Maesa & & . & 4 \\
\hline Julia Titi & I & Severus Alexan & ider & .. & I7 \\
\hline Domitian & I3 & Julia Mamaea & & .. & 2 \\
\hline Nerva .. & 7 & Maximinus Th & $\operatorname{rax}$ & .. & I \\
\hline Trajan .. & 38 & Gordianus Pius & & .. & I \\
\hline Hadrian & 36 & & & & \\
\hline Sabina ... & 3 & Total & . & . & 337 \\
\hline $\begin{array}{lll}\text { Aelius } . . & .\end{array}$ & I & & & & \\
\hline Antoninus Pius & 25 & & & & \\
\hline Faustina senior. & 9 & & Siliq & & \\
\hline Marcus Aurelius & I7 & Constantius II & .. & .. & 2 \\
\hline Faustina junior & 4 & Julian . . & . & . & 3 \\
\hline Lucius Verus . & 2 & Valentinian I & .. & .. & 3 \\
\hline Lucilla ... & I & Valens $\quad .$. & . & . & I \\
\hline Commodus . & 8 & Gratian & . & .. & I \\
\hline Septimius Severu & 23 & & & & - \\
\hline Julia Domna & I 5 & Total & .. & .. & IO \\
\hline
\end{tabular}

Totals :-denarii, 337 ; siliquae, Io; undeciphered, I2. Sum total, 359.

The occupation of Corstopitum dates from the reign of Domitian. It is evident, therefore, that, in the course of his reign and probably for some years after it, denarii of Galba, Vitellius, Vespasian and

${ }_{1}$ Archaeologia Aeliana, $3^{\text {rd }}$ ser. vols. iii-viii, xii. 
Titus were circulating in very large numbers. The legionary coins of Mark Antony, for the most part worn to disks, were also plentiful. On the other hand, Republican silver, though still passing, was becoming scarce, and the silver of the early empire anterior to Nero's monetary changes had practically disappeared. There is nothing new in these facts, and there is more to be learned from the bronze coins of this period found at Corbridge. Of these, prior to the death of Titus, we have one illegible Greek piece, a coin of the Lycian League (i.e. before A.D. 43), one of Drusus belonging to the reign of Tiberius, one of Germanicus struck by Caligula, two of Nero, thirtynine of Vespasian, eleven of Titus, and two at least of Domitian. An interesting feature is that, with the exception of one coin of A.D. 7I, there are no sesterces earlier than the death of Vespasian. Evidently this species of bronze currency had, at this period at all events, a much shorter life than dupondii or asses.

For the sole reign of Domitian there are only eight, or at most ten, silver coins; and his reign, in the course of which Corstopitum was first occupied, is consequently much less well represented than are the reigns of his immediate predecessors. This paradoxical result might be difficult of explanation were it not that exactly the same phenomenon has been noted in regard to hoards of Roman silver found in Germany. The solution seems to be that early Flavian. silver was circulating in such plenty on the confines of the empire during the reign of Domitian that there was no necessity for the exportation of newly-minted coin. The fact that all but one of the eight denarii of Domitian belong to the latter half of his reign accords with this hypothesis. Bronze currency was not similarly affected : Corstopitum has yielded forty-six bronze coins of Domitian, and all but two or three belong to his sole reign.

A summary of the silver coins of the second century has already been given. Turning now to the bronze, we have the following: Nerva, II ; Trajan, I05; Hadrian, 92 ; Sabina (issued by Hadrian), 4; Antoninus Pius, 56; Faustina the elder (issued by Pius), I5; Marcus Aurelius, 22 (of which about twelve were issued by Pius); Faustina the younger, 20 (of which about twelve were issued by Pius); Luicilla, I (issued by Marcus); Commodus, 7 (of which at least two were issued by Marcus); Crispina, 2 (issued by Marcus or Commodus). Arranged under reigns, they give the following results :-

\begin{tabular}{|c|c|c|c|c|c|c|c|c|c|}
\hline $\begin{array}{l}\text { Emperor. } \\
\text { Nerva }\end{array}$ & & & & & & & $\begin{array}{l}\text { Years of } \\
\text { sole reign. }\end{array}$ & $\begin{array}{l}\text { Silver } \\
\text { coins. }\end{array}$ & $\begin{array}{l}\text { Bronze } \\
\text { coins. }\end{array}$ \\
\hline Nerva .. & .. & .. & . & $\cdots$ & & $\cdots$ & 2 & 7 & II \\
\hline Trajan .. & .. & . . & .. & . & . . & .. & 19 & $3^{8}$ & 105 \\
\hline Hadrian & . & . & .. & .. & . & .. & $2 I$ & 40 & 96 \\
\hline Pius .. & . & . & .. & .. & . & . & 23 & 39 & 95 \\
\hline Marcus & .. & .. & . & . & .. & .. & I9 & 18 & 22 (about) \\
\hline Commodus & $\ldots$ & $\ldots$ & $\ldots$ & $\ldots$ & .. & $\ldots$ & 12 & 8 & 6 (about) \\
\hline
\end{tabular}


From these figures it appears that throughout the reigns of Trajan, Hadrian and Pius, there was a steady and uninterrupted flow of newly-minted coin into Corstopitum, proceeding with perfect regularity; but from the accession of Marcus Aurelius the supply of silver sinks to one-half and that of bronze to one-quarter. Under Commodus the proportions are further reduced to one-third and one-tenth respectively.

Changes in the character of currency are, in the absence of comparative data, best left unexplained, for a priori reasoning is often no better than guesswork. Where they are explicable, the reason is to be sought either in general considerations affecting currency, or in the history of the particular locality. Chief among the general causes is a depreciation of coinage, which normally leads to an increased circulation of new issues, partly because the purchasing power of the coin is reduced, and partly as the result of Gresham's law-the tendency of bad coin to drive out good. But though this is the normal, it is not the invariable result of depreciation. On the outskirts of the empire, and particularly on the German frontier, where money was largely employed in foreign trade, it seems to have been found impossible to get depreciated coin accepted; and the older issues, instead of being driven out of circulation, actually became the sole medium of exchange.

At Corstopitum a local explanation is fortunately to hand. The great gold hoard found there in I9I I had for its latest item an aureus of A.D. I 59, and the hoard itself must have been buried within two or three years of that date. Other circumstances point to a time of stress, and probably to a partial destruction, as occurring in the opening years of the reign of Marcus. There was some rebuilding, but Corstopitum does not appear to have recovered the prosperity which it had enjoyed under Antoninus Pius. The diminution of silver currency under Marcus and Commodus is merely an additional proof of what can be guessed from other sources.

It is less easy to account for the falling-off of bronze coinage in increased ratio. The influx of new bronze coin steadily diminished under Marcus and Commodus, and after A.D. 192 it ceased altogether. Later bronze currency, prior to the introduction of the debased ' antoninianus,' is represented solely by a large bronze piece of Septimius Severus from a Greek city in Asia Minor-not a coin in the strict sense, a Greek coin of Severus Alexander (also from Asia Minor), and two coins of Julia Mamaea, the mother of Alexander ; whereas for the same period we have no fewer than ninety-nine denarii. It is true that under Commodus there was a decreased output of bronze types throughout the empire, and that after Severus Alexander they became rare; but at Corstopitum the discrepancy between silver and bronze is wholly remarkable, and it will be interesting to observe in what other areas and in what 
classes of settlement the same phenomenon occurs, for there is no reason for supposing Corstopitum to be an isolated instance. The fact may be that earlier bronze issues, which had previously had a short life, were retained in circulation under Marcus and his immediate successors, owing to the waning supply of new coin. But bronze coins cannot be passed from hand to hand indefinitely, and quite early in the third century the currency must have come to consist almost solely of debased denarii. If these conditions were in any degree general, the subsequent debasement of the 'antoninianus' acquires a new significance, since it met the inconveniences that must undoubtedly have been caused by the disappearance of the smaller denominations.

Reverting to the silver coinage of the house of Severus, we find that a large output characterises the reign of Septimius himself. The percentage of alloy in the denarius now amounted to 50 per cent. as compared with five to ten per cent. in the Neronian denarius, so the increase in the amount of silver currency is more apparent than real, but, even so, it is well up to that which characterised the first half of the second century. The quantity of new coin. imported at this time appears to have more than satisfied requirements, and during the sole reign of Caracalla, which is represented by a single denarius, the import of bullion was temporarily suspended. With Elagabalus there is a further outcrop of new issues, but under Alexander the supply of silver is again somewhat restricted. These fluctuations must be taken as devoid of special significance except so far as they indicate different conditions from those obtaining in the first half of the second century, when the import of bullion into northern Britain proceeded with unfailing regularity.

The only other feature of the Corbridge silver-supply that need here be noticed is that it was limited to one denomination, the denarius. Quinarii have not been found at all, and 'antoniniani,' although freely coined under Caracalla and Elagabalus, do not make their appearance here until the reign of Gordian, who was also the last emperor to issue denarii in any number : in other words, the 'antoninianus' was not employed here for purposes of exchange solong as there was a supply of denarii.

\section{CATALOGUE OF ROMAN SILVER COINS}

FOUND IN THE EXCAVATIONS AT CORSTOPITUM IN IgO6 TO I9I2.

\section{ROMAN REPUBLIC.}

UNideNTIFIEd (87-8r r.c.).

r. Obv. Female head r.

Rev. Charioteer in triga, horses galloping.
Manivs Acilivs Glabrio (50 B.c.).

2. Obv. salvris. Laureate head of Salus r. Rev. IIIVIRVALETV Macilivs. Salus standing 1 , feeding serpent and leaning 1 . arm on column.

Grueber, i, p. 496 , no. 3943 . 
Avlvs Licinivs Nerva (48 B.c.).

3. Obv. alicinivs to 1 . of head, Fides to $\mathrm{r}$. of head : the inscriptions read from 1 . to $r$. Laureate head of Fides r.

Rev. NERVA in exergue, III VIR round edge. Horseman galloping $\mathrm{r}$.

Grueber, i, p. 515, no. 4002 .

Caivs Cassivs Longinvs (43-42 B.c.).

4. Obv. c.Cassi-imp leibertas. Veiled head of Libertas $r$.

Rev. [Lentvlvs spint] Sacrificial instruments (capis and lituus).

Grueber, ii, p. 48 I, no. 73 .

5-8. Marcvs Antonivs (32-3i B.c.).

5. Obv. ANT.Avg above, III $\cdot V I R \cdot R \cdot P \cdot C$ below. Praetorian galley.

Rev. LEG viI. Legionary eagle between two military standards.

Grueber, ii, p. 528 , no. 198 . Three specimens.

6. Obv. as no. 5 .

Rev. as no. 5 but LEG XIII.

Grueber, ii, p. 529, no. 205. Two specimens, one countermarked NCAESAR.

7. $\mathrm{Obv}$. as no. 5 .

Rev. as no. 5 but LEG XVII (?)

Grueber, ii, p. 529, no. 212.

8. Obv. as no. 5 .

Rev. as no. 5 but LEG XIX.

Grueber, ii, p. 529, no. 214.

Sixteen undeciphered.

\section{IMPERIAL COINS.}

\section{Avgvstvs (27 B.C.-A.D. 14).}

9. Obv. Head of Augustus r, behind it an augur's baton.

Rev. Indecipherable.

$$
\text { io-i i. Galba (a.d. 68-69). }
$$

io. Obv. impsergalbacaesaravg. Head r, laureate.

Rev. salvsgen hymani. Salus standing 1 . by lighted altar, r. foot resting on globe, holding patera in $r$. hand and rudder (?) in 1 .

Cohen, i, p. 335, no. 238.

II. Obv. IMP SER Galba Avg. Head r, bare.

Rev. SPQR $\mid$ OB $\mid$ C.s in three lines within an oak-wreath.

Cohen, Ist edition, i, p. 226, no. 8I : not in 2 nd edition. Two specimens.

$$
\text { I2-I4. Vitellivs (A.D. 69). }
$$

1.2. Obv. avitellivigermimpavgtrp. Head $r$, laureate.

Rev. CONCOR DIAPR. Concordia seated 1, holding patera in $r$. hand and double cornucopiae in 1 ; in exergue $x$.

Cohen, i, p. 357 , no. 18 . Two specimens.

13. Obv. AVITELIIVSGERMANimptrp. Head r, laureate.

Rev. as no. I2.

Cohen, i, p. 357, no. 20.
14. Obv. avitellivsgermanicvisimp. Head r. bare.

Rev. as no. I2.

Cohen, i, p. 357 , no. 2 r.

$$
\begin{aligned}
& \text { I5-30. Vespasian. } \\
& \text { Cos. II (A.D. 7O). }
\end{aligned}
$$

15. Obv. impcaesarvespasianvsavg. Head r, laureate.

Rev. cositer TRPOT. Mars, nude and helmeted, advancing $r$, holding spear aslant in $r$. hand and in 1 . a trophy on his shoulder.

Cohen, i, p. 375 , no. 88.

16. Obv. as no. 15 .

Rev. cositer trpot. Fortuna seated 1 , holding branch in $r$. hand and caduceus in 1 .

Cohen, Ist edition, vii, p. 57 , no. $8:$ not in 2nd edition. Five specimens.

17. Obv. as no. 15.

Rev. Cositer trpot. Aequitas standing 1 , holding scales in $r$. hand and cornucopiae in 1 .

$$
\text { Cos. IV (A.D. } 72-73 \text { ). }
$$

18. Obv. impcaesvespaygrmcosinit. Head r, laureate.

Rev. avgrr above, tripot below. Simpulum, aspergillum, lecuthos and augur's staff.

Cohen, i, p. 37r, no. 45. Two specimens.

I9. Obv. as no. I8.

Rev. VES TA in field. Vesta standing 1, holding simpulum in $\mathrm{r}$. hand and sceptre in 1 .

Cohen, i, p. 413, no. 574 .

20. Obv. as no. I 8 .

Rev. victoria avgvsti. Victoria advancing $r$, placing wreath on a military standard and holding palm in 1 . hand.

Cohen, rst edition, $i$, p. 296, no. 229. The same piece is less correctly described in the 2nd edition (i, p. 416 , no. 618).

21. Obv. impCaesves [PAVGPM]. Head r, laureate.

Rev. as no. I8.

Cohen, i, p. 37i, no. 43 .

\section{UNDATED.}

22. Obv. impCaesarvespasianvsavg. Head r, laureate.

Rev. IVDAEA in exergue. Judaea as a captive seated $\mathrm{r}$; behind, a trophy.

Cohen, i, p. 384 , no. 226, c. A.D. 71. Three specimens.

23. Obv. impcaesvespavgcen. Head r, laureate.

Rev. $\mathrm{SPQR}$ within an oak-wreath.

Cohen, i, p. 408, no. 5 I6, c. A.D. 73-75.

24. Obv. impcaesvesp avgcens. Head r, laureate. On this and on the succeeding denarii of Vespasian the obverse legend reads from $r$. to $l$. 
Rev. PONTIF MAXIM from r. to 1 . Vespasian enthroned $r$, holding sceptre in $r$. hand and branch in 1 .

Cohen, Ist edition, i, p. 289 , no. I64; not in 2 d edition; c. A.D. 73-75. Four specimens.

$$
\text { Cos. VI (A.D. 75). }
$$

25. Obv. impcaesarvespasianvsavg. Head r, laureate.

Rev. PONMAX TRPcosvi. Victory standing 1. on prow of vessel, holding wreath in r. hand and palm in 1 .

Cohen, i p. 395 , no. 368 .

26. Obv. as no. 25

Rev. PONMAX TRPCos̄̄i. Female figure seated 1 , resting 1 . arm on back of seat.

Cohen, i, p. 395 , no. $3^{66}$.

$$
\text { Cos. viI (A.D. } 76 \text { ). }
$$

27. Obv. as no. 25

Rev. cos vir. Eagle on cippus with wings spread, head turned 1.

Cohen, i, p. 377 , no. I2 I. Two specimens.

$$
\text { Cos. vili (A.D. } 77 \text { or } 78 \text { ). }
$$

28. Obv. impcaesarvespasianvsavg. Head 1 , laureate.

Rev. cos viri. Mars, nude and helmeted, with cloak hanging from his shoulders, standing $\mathrm{l}$, holding in $\mathrm{r}$. hand a transverse spear and in 1. a trophy: behind him an ear of corn.

Cohen, i, p. 377 , no. 127 , where the type is imperfectly described.

$$
\text { Cos. IX (A.D. 79). }
$$

29. Obv. impcaesarVespasianvSAvg. Head r, laureate.

Rev. [Trpotx cosvini]. Statue on column.

Cohen, i, p. 4I I, no. 559 .

\section{Commemorative Coin.}

30. Obv. Divvsavgvstvsvespasianvs. Head r, laureate.

Rev. SC on shield supported on the backs of two capricorns.

Cohen, i, p. 406, no. 497 .

Four undeciphered.

\section{I-35. Titus (A.D. $7 \mathrm{I}-8 \mathrm{I}$ ). UNDATED.}

3I. Obv. [TCAesimpvespcens]. Head r, laureate.

Rev. FIDEs PVBL. Two clasped hands holding a caduceus, two ears of grain and two poppies.

Cohen, i, p. 436 , no. 87 .

$$
\text { Cos. V (A.D. 76). }
$$

32. Obv. TCAESAR IMPVESPASIAN from $r$. to 1 . Head r, laureate.

Rev. cos v in field. Eagle on cippus with wings spread, head turned 1 .

Cohen, Ist edition, vol. i, p. 344 , no. 23 ; vol. vii, p. 70 ; not in 2 nd edition.
Trib. Рot. ix, Cos. vili (a.D. 80).

33. Obv. ImptitvscaesvespasianavgPM from $\mathrm{r}$. to 1 . Head r, laureate.

Rev. TRPIXIMpxvcosviripp. Tusked elephant standing 1 .

Cohen, i, p. 454, no. $3 \circ 3$.

34. Obv. as no. 33 .

Rev. TRPIxImpxvcosviIIPP. Winged thunderbolt resting on throne.

Cohen, i, p. 455 , no. 3 I6.

35. Obv. as no. 33 .

Rev. TRPIXIMPXVCosviIIPP. Wreath resting on curule chair.

Cohen, i, p. 455 , no. 318. Two specimens. One undeciphered.

$$
\text { Iulia (daughter of Titus). }
$$

36. Obv. ivliaavgvitatavgf from r. to 1 . Draped bust $r$, hair in queue.

Rev. venvs avg from r. to 1 . Venus, nude, standing $r$, with back turned and leaning on column, holding helmet in $r$. hand and spear pointed downwards in 1 .

Cohen, i, p. 466, no. 12.

$$
\begin{aligned}
& \text { 37-47. Domitian (A.D. 69-96). } \\
& \text { Cos. v (A.D. 76). }
\end{aligned}
$$

37. Obv. caesaravgfoomitianvs from $\mathrm{r}$. to 1 . Head r, laureate.

Rev. $\cos \mathrm{v}$ in exergue. Wolf 1. suckling Romulus and Remus.

Cohen, i, p. 474 , no. 5 I

38. Obv. Caesaravgfdomitianvscos $\overline{\mathrm{v}}$ from $\mathrm{r}$. to 1. Head r, laureate.

Rev. PRINCEPS IVVENTVTIS. Salus standing 1. feeding serpent and leaning on column. Cohen, i, p. 503: no. 384 .

$$
\text { Cos. vi (A.D. } 77-79 \text { ). }
$$

39. Obv. Caesaravgfdomitianvscosvi from $r$. to 1 . Head r, laureate.

Rev. PRINCEPS IVVENTVTIS. Vesta seated 1.

holding palladium in r. and sceptre in 1.

Cohen, i, p. $5 \circ 3$, no. $37^{8}$.

Trib. Pot. v, Cos. Xil (A.D. 86).

40. Obv. impcafsdomitavggermpmtrpy. Head $r$, laureate.

Rev. ImpXicosXI censppp. Pallas helmeted standing $r$, poising javelin in $r$. hand and holding shield on 1 . arm.

Cohen, i, p. 489, no. I 94 .

Trib. Pot. vili, Cos. xiv (A.D. 89)

41. Obv. IMPCAESDOMITAVG GERMPMTRPVIII. Head r, laureate.

Rev. ImPXixcosxiIIICENSPP. Pallas helmeted standing l, holding thunderbolt in r. hand and spear in 1 , at her feet a shield. Cohen, i, p. 493, no. $25 \mathrm{I}$.

Trib. Pot. ix, Cos. xiv (A.D. 80).

42. Obv. IMPCAESDOMITAVG GERMPMTRPVIIII Head r, laureate.

Rev. as no. 4I but IMPXXicosXiIII CENSPPP.

Cohen, i, p. 493 , no. 256 . 
Trib. Рot. xi, Cos. xv (A.D. 9I). 43. Obv. IMPCAESDOMITAVG GERMPMTPRXI. Head r, laureate.

Rev. as no. 40 but IMPXXICOSXVCENSPPP.

Cohen, i, p. 494, no. 269.

Trib. Рot. xi, Cos. xvi (A.D. 92).

44. Obv. as no. 43 .

Rev. as no. 40 but IMPXXICOSXVICENSPPP.

Cohen, i, p. 494, no. 273.

45. Obv. as no. 43 .

Rev. ImpXxicosxvicensppp. Pailas helmeted standing $r$. in a vessel, poising javelin in $r$. hand and holding shield in $l$, at her feet an owl.

Cohen, i, p. 494, no. 274 .

Trib. Рot. xv, Cos. xvil (A.D. 95 or 96). 46. Obv. impCaesdomitavg GeRmpMtRPXV. Head r, laureate.

Rev. as no. 40 but IMPXXIICOSXVIICENSPPP.

Cohen, i, p. 496, no. 292.

47. Obv. as no. 46.

$R e v$. as no. 45 but IMPXXIICOSXVIICENSPPP.

Cohen, i, p. 496, no. 293 .

Two undeciphered.

48-53. Nerva (A.D. 96-98).

Trib. Pot. I, Cos. II (A.D. ${ }^{6}$ ).

48. Obv. ImpNeRVACAesavg PMTRPCOSIIPP. Head $r$, laureate.

Rev. FORTVNA PR. Fortuna seated 1, holding branch in $r$. hand and sloping sceptre in 1.

Cohen, ii, p. 8 , no. 76 .

Trib. Pot. I, Cos. in (A.D. 97).

49. Obv. impnervacaesaygrmtrpot. Head $\mathrm{r}$, laureate.

Rev. Cosilipaterpatriae. Simpulum, aspergillum, urceus and augur's staff.

Cohen, ii, p. 6, no. 48 .

50. Obv. IMPNERVACAeSAVG PMTRPCOSIIIPP.

Head r, laureate.

Rev. as no. 48.

Cohen, ii, p. 8, no. 79 .

Trib. Рot. if, Cos. ili (A.D. 97).

5I. Obv. IMPNERVACAESAVG PMTRPIICOSIIIPP.

Head r, laureate.

Rev. aeqvitas avgvst. Aequitas, crowned with modius, standing l, holding scales in $r$. hand and cornucopiae in $l$.

Cohen, ii, p. 2, no. 9 .

52. Obv. as no. $5 \mathrm{I}$.

Rev. CONCORDia exercitvvm. Two hands clasped.

Cohen, ii, p. 3, no. 22. Two specimens.

\section{Date Uncertain.}

53. Obv. impnervacaesavgpmtrp .... Head $r$, laureate.

Rev. FORTVNa AVGVST. Fortuna standing 1 , holding rudder in $\mathrm{r}$. hand and cornucopiae in 1 .

\author{
54-79. Trajan (A.D. 98-II7). \\ Cos. II (A.D. 98 OR S9).
}

54. Obv. impcaesnervatrai anavggerm. Head $r$, laureate.

Rev. PMTrpcosirp.P. Female figure, diademed, seated 1 . in chair of which the arms terminate in cornucopiae, holding sceptre in $r$. hand and resting l. elbow on arm of chair.

Cohen, ii, p. 40, no. 206.

$$
\text { Cos. III (A.D. IOO). }
$$

55. Obv. as no. 54 .

Rev. PMTRP cosinipp. Hercules, nude, standing facing on cippus, holding club in r. hand, a lion's skin hung over l. arm.

Cohen, ii, p. $4 \mathrm{I}$, no. 215 .

56-7. Obv. as no. 54 .

Rev. PMTRP cosinpp. Concordia seated 1, holding patera in $r$. hand and double cornucopiae in 1 , in front of her a lighted altar.

Cohen, ii, p. 42, no. 227. Two specimens.

$$
\text { Cos. IV (A.D. IOI-IO3). }
$$

58. Obv. as no. 54 .

Rev. PMTrP cosinipp. Mars marching $r$, holding spear advanced in $r$. hand and trophy on 1 . shoulder.

Cohen, ii, p. 42 , no. 228 .

59. Obv. as no. 54 .

Rev. $\mathbf{P} \cdot \mathrm{M} \cdot \mathrm{TR} \cdot \mathrm{P} \cdot \cos \cdot \mathrm{IIII} \cdot \mathrm{P} \cdot \mathbf{P} \cdot$ Hercules as in no. 55 .

Cohen, ii, p. 43 , no. 234

6o. Obv. as no. 54 .

Rev. PMTRPCosinipp. Victory advancing 1 , holding wreath in $r$. hand and palmbranch in 1 .

Cohen, ii, p. 43 , no. 242. Two specimens.

$$
\text { Cos. V (A.D. IO4-III). }
$$

6r. Obv. IMPTRAIANOAVGGERDACPMTRP. Bust $r$, laureate, a fold of drapery shows over the l. shoulder.

Rev. COSVPPSPQROPTIMOPRINC. Aeternitas veiled, standing 1 , holding head of Sol in $r$. hand and head of Luna in 1, in field AET AVG.

Cohen, ii, p. 18, no. 3 .

62. Obv. as no. 6r.

Rev. COSVPPSPQROPTIMOPRINC. Soldier armed and helmeted standing 1, holding a Victory in $r$. hand and spear in 1 .

Cohen, ii, p. 25 , no. 68 . Two specimens.

63. Obv. as no. 6r.

Rev. COSVPPSPQROPTIMOPRINC. Victory standing 1 , holding wreath in $r$. hand and palm-branch in 1 .

Cohen, ii, p. 26, no. 74. Four specimens. 64. Obv. as no. 61 .

Rev. CosvPPSPQRoptimoprinc. Aequitas standing 1 , holding scales in $r$. hand and cornucopiae in 1 .

Cohen, ii, p. 27 , no. 85 , where the piece is is given in error as gold. Two specimens. 
65. Obv. as no. 6r.

Rev. as no. 64 but Aequitas is seated.

Cohen, ii, p. 27 , no. 86.

66. Obv. as no. 6r.

Rev. COSVPPSPQROPTIMOPRINC. Fortuna standing 1 , holding rudder in $r$. hand and cornucopiae in 1 .

Cohen, ii, p. 27 , no. 87 .

67. Obv. as no. 61 .

Rev. COSVPPSPQROPTIMOPRINC. Arabia standing 1 , holding branch in $\mathbf{r}$. hand and reed in l, before her a camel.

Cohen, ii, p. 27 , no. 89 .

68. Obv. as no. 6r.

Rev. COSVPPSPQROPTIMOPRINC. Trophy hung with round and oval shields, a pile of arms at the foot.

Cohen, ii, p. 28, no. 98 .

69. Obv. IMPTRAIANOAVGGERDACPMTRPCOSVPP. Bust $r$, laureate, a fold of drapery falls over 1. shoulder.

Rev. SPQROPTIMOPRINCIPI. Ceres veiled standing 1 , holding ears of grain in $r$. hand and flambeau in 1 .

Cohen, ii, p. 56 , no. 366 .

70. Obv. as no. 69 but bust is fully draped.

Rev. SPQROPTIMOPRINCIPI. Mars helmeted standing $r$, holding spear in $r$. hand and resting 1 . on a shield supported by a kneeling captive.

Cohen, ii, p. 57 , no. 377 .

7r. Obv. as no. 69 .

Rev. SPQROPTIMOPRINCIPI. Genius standing 1 , holding patera in $r$. hand and cornucopiae in 1 , before him a lighted altar.

Cohen, ii, p. 59, no. 394.

72. Obv. as no. 69 .

Rev. SPQROPTIMOPRINCIPI. Soldier helmeted standing $r$, with 1 . foot on helmet, resting on spear held in r. hand and holding parazonium in 1 .

Cohen, ii, p. 60, no. 402.

73. Obv. as no. 69 .

Rev. SPQROPTIMOPRINCIPI. Pax standing 1 , holding caduceus in $r$. hand and cornucopiae in 1 , before her an altar.

Cohen, ii, p. 60, no. 412 .

$$
\text { Cos. vi (A.D. II 2-II4). }
$$

74. Obv. IMPTRAIANVS AVGGERDACPMTRPCOSVIPP. Bust $r$, laureate, a fold of drapery falls over 1 . shoulder.

Rev. Divvspatertraian. Trajanus pater seated 1 . in curule chair, holding patera in $r$. hand and sceptre in 1.

Cohen, ii, p. 33, no. 140 .

75. Obv. IMPTRAIANOAVGGERDACPMTRPCOSVIPP. Bust $r$, laureate, a fold of drapery falls over 1. shoulder.

Rev. SPQROPTIMOPRINCIPI. Alimonia standing 1 , holding ears of grain in $\mathbf{r}$. hand and cornucopiae in 1, before her a child, in exergue alimital.

Cohen, ii, p. 18, no. 9 .
76. Obv. as no. 75 but bust is fully draped.

Rev. SPQROPTIMOPRINCIPI. Arabia standing 1 , holding branch in $\mathrm{r}$. hand and reed in 1 , in exergue ARABADQ.

Cohen, ii, p. 20 , no. 26.

Optimus, Cos. vi (A.D. II4-116).

77. Obv. IMPCAESNERTRAIANOOPTIMOAVGGERDAC. Bust r, laureate and draped.

Rev. PMTRPCos viPPSPQR. Column surmounted by statue of Trajan holding sceptre in l. hand, two eagles at base of column.

Cohen, ii, p. 47 , no. 284 .

Parthicus, Cos. vi (A.D. II6 OR I I7).

78. Obv. IMPCAESNERTRAIANOPTIMAVGGERMDAC. Bust $\mathrm{r}$, laureate and draped.

Rev. PARTHICOPMTRPCOSVIPPSPQR. Mars nude and helmeted marching $r$, carrying spear in r. hand and trophy over 1 . shoulder.

Cohen, ii, p. 38 , no. 190.

79. Obv. as no. 78 .

Rev. PARTHICo PMTRPCOSVIPPSPQR. Providentia standing 1 . holding sceptre in 1. hand, before her on the ground a globe, in field $P R O$ vID.

Cohen, ii, p. 50, no. 314 .

Six undeciphered.

80-IO8. Hadrian (a.d. II 7-r38).

Cos. I (A.D. II 7 ).

80. Obv. [IMPCAESTRAIANHADRIANOAVGDIVITRA] Bust r, laureate.

Rev. PARTHFDIVINERNEPPMTRPCO5. Pax standing 1 , holding olive-branch in $\mathrm{r}$. hand and cornucopiae in 1 , in exergue Pax.

Cohen, ii, p. r9o, no. ror r.

8r. Obv. [IMPCAESARTRAianhadRIANVSAVg]. Bust $r$, laureate.

Rev. pMtrpcospesir. Similar design to no. 80 (?).

Cohen, ii, p. r92, no. 1049 (?).

$$
\text { Cos. II (A.D. II } 8 \text { ). }
$$

82. Obv. impCaesartraianhadrianvsavg. Bust r. laureate, folds of drapery are seen over 1. shoulder.

Rev. PMTRP cosir. Justitia seated 1, holding patera in r. hand and sceptre in 1 , in exergue Ivstitia.

Cohen, ii, p. r8o, no. 877 .

83. Obv. as no. 82.

Rev. PMtrp cosdesirir. Salus seated 1 , feeding a serpent entwined round an altar, 1. arm resting on chair, in exergue SALVS AVG.

Cohen, ii, p. 218 , no. 1352 .

$$
\text { Cos. III (A.D. II9-I27). }
$$

84. Obv. as no. 82 .

Rev. PMTrp cosiri. Aeternitas standing facing, holding head of Sol in r. hand and head of Luna in 1, in field AETER Avg.

Cohen, ii, p. II6, no. r3I, c. A.D. 120. 
85. Obv. as no. 82 but bust is fully draped.

Rev. PMTRP cosiII. Libertas seated 1 holding laurel-branch in r. hand and sceptre in 1 , in exergue LIBPVB.

Cohen, ii, p. I8I, no. 903 , c. A.D. I2I.

86. Obv. as no. 82 .

Rev. PMtrp cosirr. Pax standing l, holding olive-branch in $r$. hand and cornucopiae in 1 , in exergue Pax.

Cohen gives this type only with coins of the second consulship.

87. Obv. as no. 85 .

Rev. PMTRP cosiri. Roma helmeted seated 1, holding Victory in r. hand and spear in 1 .

Cohen, ii, p. 197, no. 1098, c. A.D. 123.

88. Obv. as no. 82 .

Rev. PMTRP cosin. Oceanus recumbent 1 , holding anchor uplifted in r. hand and resting 1 . arm on a dolphin.

Cohen, ii, p. I99, no. IIIO, c. A.D. I23.

89. Obv. as no. 82 .

Rev. PMTrp cosirr. Aequitas standing 1, holding scales in $r$. hand and cornucopiae in 1 .

Cohen, ii, p. I99, no. I120, c. A.D. 122. Two specimens.

9०. Obv. as no. 82 .

Rev. PMTrp cosirr. Salus seated 1, feeding from a patera a serpent entwined round altar and resting 1 . arm on seat, in exergue SALVS AVG.

Cohen, ii, p. 218 , no. I353, c. A.D. I 19.

91. Obv. Hadrianvs avgvstvs. Bust r, laureate, a fold of drapery falls over 1 . shoulder.

Rev. cos IIr. Roma helmeted seated r. on a cuirass, holding spear in $r$. hand and parazonium in 1 , behind her a shield, in exergue a globe.

Cohen, ii, p. 135 , no. 337; c. A.D. 127

92. Obv. as no. 9r.

Rev. cos III. Soldier armed and helmeted standing 1 , holding Victory in r. hand and spear in 1.

Cohen, ii, p. 136, no. 349, c. A.D. 125.

93. Obv. as no. 91.

Rev. cos Irr. Spes advancing to 1, holding flower in r. hand and holding up skirt with 1.

Cohen, ii, p. I39, no. 390, c. A.D. I24.

94. Obv. as no. 91.

Rev. cos III. Star over a crescent.

Cohen, ii, p. 145 , no. 460 , c. A.D. 127.

95. Obv. as no. 91.

Rev. cos III. Seven stars over a crescent.

Cohen, ii, p. 145 , no. 466 , c. A.D. 127.

Cos. iII, Pater Patriae (A.D. 127-138).

96. Obv. Hadrianvs avgvistvspr. Head $\mathbf{r}_{\text {, }}$ laureate.

Rev. cos IIr. Aequitas as in no. 89.

Cohen, ii, p. $13^{8}$, no. $3^{82}$, c. A.D. 127 .
97. Obv. Hadrianvs avgvstvs. Head r, bare.

Rev. TRANQVILLIT asavgcosimpp. Tranquillitas standing 1 , holding sceptre in $r$. hand and resting 1 . hand on hip.

Cohen gives this type only with the bust on the obverse draped and cuirassed (p. 225, no. 1440), c. A.D. 129.

98. Obv. [hadrianvs avgcosimpr]. Head 1 , laureate.

Rev. [FELICITATI above], avgrsti below. Galley with rowers.

Cohen, ii, p. 167 , no. 7 r3, c. A.D. 130.

99. Obv. Hadrianvs avgcosimpr. Head r, bare.

Rev. FIDEs pvBlica. Fides standing facing, head turned to $r$, holding ears of grain in $r$. hand and dish of fruit in 1.

Cohen, ii, p. 168, no. 7 16, c. A.D. I 31 .

100. Obv. Similar to no. 99, but head 1 .

Rev. as no. 99.

Cohen, ii, p. 168, no. 718, c. A.D. I31.

ror. Obv. Hadrianvs AVgcosiripp. Bust r, laureate and draped.

Rev. FORTVNAE REDVCI. Design indecipherable.

c. A.D. 134 or 135 .

102. Obv. HADRIANVS AvgcosIIIPP. Bust $r$ draped, bare-headed.

Rev. MAR Tr. Mars helmeted standing 1, holding spear in $r$. hand and resting 1. hand on a shield.

Cohen, ii, p. I85, no. 95 r. c. A.D. I 32.

103. Obv. as no. 99 .

Rev. ROMA FELIx. Roma helmeted seated 1 , in curule chair, holding olive-branch in $r$. hand and spear in 1 .

Cohen, ii, p. 215 , no. 1304, c. A.D. 130.

104. Obv. Hadrianvs avgcosimipp. Head r, laureate.

Rev. Salvs Avg. Salus standing $r$, feeding with the $r$. hand a serpent rising from an altar, and holding a patera in 1 .

Cohen, ii, p. 216 , no. 1334 , c. A.D. 138 .

105. Obv. as no. 99 .

Rev. as no. 104 .

Cohen, ii, p. 216 , no. 1335 , c. A.D. 138.

ro6. Obv. as no. 99 .

Rev. VICTORIA Avg. Victoria standing r, holding laurel-branch.

Cohen, ii, p. 227, no. I454, c. A.D. I 32.

107. Obv. as no. 99.

Rev. victo RIAavg. Victoria seated 1, holding wreath in $r$. hand and palmbranch in 1 .

Cohen, ii, p. 227, no. 1461 , c. A.D. 132.

108. Obv. as no. 99 .

Rev. vota PVBLICA. Hadrian veiled standing 1 , holding in $r$. hand a patera with which he sacrifices at a tripod, with the 1. hand he holds up the folds of his toga. Cohen, ii, p. 229, no. I48 r, c. A.D. 133.

Six undeciphered.

ro9-r ro. Sabina (wife of Hadrian).

rog. Obv. sabina avgvsta. Bust $r$, diademed and draped, hair in a queue.

Rev. Concor DIAAvg. Concordia seated 1 , holding patera in $r$. hand and sceptre in 1 . Cohen, ii, p. 249, no. 24, c. A.D. 128-9. 
I10. Obv. as no. rog.

Rev. VENERI GeNeTrici. Venus standing $r$, with her $r$. hand she raises drapery from her shoulder, in her 1. she holds an apple.

Cohen, ii, p. 253 , no. 73 , c. A.D. 135 .

One undeciphered.

\section{Aelius (A.D. I $3^{6-1} 37$ ).}

III. Obv. taelivs caesar. Head r, bare.

Rev. TrPót cosir. Pietas veiled standing

1. by altar, raising r. hand and resting

1. hand on her hip.

Cohen, ii, p. $26_{3}$, no. 53

1 1 2-130. Antoninvs Pivs (A.D. 138-16i).

$$
\text { Cos. III (A.D. I40-I44). }
$$

I 12. Obv. Antoninvsavgri vspptrpcosiri. Head r, laureate.

Rev. annonaavg. Modius, in it four ears of grain and a poppy.

Cohen, ii, p. 274 , no. 33 .

II3. Obv. as no. II2.

Rev. as no. I I2, but two ears of grain and two poppies.

Cohen, ii, p. 274, no. 33 .

i 14. Obv. ANTONINVSAVGPIVS pptrpcosirit. Head r, laureate.

Rev. AVRelivscae saravgrificos. Head of Aurelius r. bare.

Cohen, ii, p. 410, no. I 5, A.D. 140.

$$
\text { Cos. IV (A.D. I45-I48). }
$$

II5. Obv. ANTONINVs Avgrivspr. Head r, laureate.

Rev. cos IIIr. Aequitas standing 1, holding scales in r. hand and sceptre in 1.

Cohen, ii, p. 295, no. 228.

I 6. Obv. as no. I I5.

Rev. cos IIIr. Two clasped hands holding a caduceus and two ears of grain.

Cohen, ii, p. 304, no. 344 .

II7. Obv. as no. in 5 .

Rev. cos iIII. Thunderbolt on a throne.

Cohen, ii, p. 304 , no. 345 .

$$
\text { Cos. iv, Trib. Pot. xir (A.D. I49). }
$$

i 8. Obv. antoninvsavg pivspptrpxiI. Head $r$, laureate.

Rev. cos IIr. Aequitas standing 1, holding scales in r. hand and cornucopiae in 1 .

Cohen, ii, p. 296 , no. 240.

i19. Obv. as no. iा8.

Rev. cos IIII. Felicitas standing 1, holding a caduceus in r. hand and cornucopiae in 1 .

Cohen, ii, p. 296 , no. 252 .

120. Obv. as no. II8.

Rev. cos IIII. Fortuna standing 1, holding a rudder in $r$. hand and cornucopiae in 1.

Cohen, ii, p. 297, no. 263. Two specimens.

i2i. Obv. as no. II 8 .

Rev. cos IIII. Annona standing 1, holding ears of grain in r. hand and an anchor in 1 , before her a modius filled with ears of grain.

Cohen, ii, p. 299, no. 284 .
Cos. iv, Trib. Pot. xiv (A.D. I 5 I).

122. $O b v$. IMPCAESTAELHADRANTONINVSAVGpivspr. Head r, laureate.

Rev. TRPOTXIIII cosiris. Tranquillitas standing $r$, holding plough in $r$. hand and two ears of grain in 1 , in exergue Trano.

Cohen, ii, p. 35 I, no. 825 .

Cos. iv, Trib. Pot. xv (A.D. 152).

123. Obv. as no. 122.

Rev. TRPOTXv cosirir. Pax veiled standing 1, holding olive-branch in $r$. hand and sceptre in 1 , in exergue Pax.

Cohen, ii, p. 325 , no. $5^{8} 5$.

Cos. iv, Trib. Рот. xvi (A.D. I53).

124. Obv. Antoninvsavg pivspptrpxvi. Head r, laureate.

Rev. cos rir. Vesta veiled standing 1, holding simpulum in r. hand and palladium in 1 .

Cohen, ii, p. 292, no. 197 .

Cos. iv, Trib. Pot. Xix (A.D. I 56).

125. Obv. Antoninvsayg pivsppimpit. Head r, laureate.

Rev. TRPOTXIX cosirir. Annona seated r, holding Amalthea's horn in both hands.

Cohen, ii, p. $36_{5}$, no. 985 .

Cos. iv, Trib. Рот. xx (A.D. I57).

I26. $O b v$, as no. 125 .

Rev. TRPOTXx cosinil. Ceres seated 1, holding torch in r. hand and resting 1 . arm on back of seat.

Cohen, ii, p. 367 , no. 1006 .

Cos. IV, TRIB. Pot. XXI, XXII or XXIII (A.D.I 58-160). 127. $O b v$, as no. II 5 .

Rev. Aeddivi avgrest. Temple of eight Corinthian columns supporting a pediment on which are sculptured reliefs, on the apex of the pediment a quadriga and at each angle is a statue; statues stand in front of each of the outer columns of the portico, and two statues are visible within the temple; in exergue of the reverse cosirir.

Cohen, ii, p. 279 , no. 3 .

Cos. iv, Trib. Pot. xxiri (A.D. I60).

128. Obv. ANTONINVSAVGPIVSPPTrPxxiII. Head $r$, laureate.

Rev. Votasvsce ptadeciir. Antoninus veiled standing 1 , holding in $r$. hand a patera over a lighted tripod-altar, and in 1. hand a roll; in exergue cosiris.

Variety not in Cohen, who gives at vol. ii, p. 378 , no. III3, a similar coin with reverse inscription vOTA SVSCEP DEC III $\cos$ IIII on the authority of Wiczay. 
Cos. iv, Trib. Рot. xxiv (A.D. I6I).

129. Obv. ANTONINVSAVGPIVSPPTRPXXIII. Head r, laureate.

Rev. pietatłavgcosirir. Pietas standing 1 , holding a child on either arm; two children stand one on either side.

Cohen, ii, p. 332, no. 631.

\section{Commemorative Coin.}

130. Obv. Divvs antoninvs. Head $\mathrm{r}$, bare.

Rev. Consecratio. Eagle with wings spread, head turned to 1 .

Cohen, ii, p. 287 , no. 154 .

Five undeciphered.

I3I-138. Favstina Senior (wife of Antoninus Pius).

Commemorative Coins struck after the death of Favstina IN A.D. I4I.

131. Obv. Diva favstina. Bust $r$, draped.

Rev. AETER NITAs. Aeternitas standing 1, holding a globe in $\mathrm{r}$. hand and a rudder in 1 .

Cohen, ii, p. 414, no. 6 .

132. Obv. Diva favstina. Bust $\mathrm{r}$, draped and veiled.

Rev. AETERni tas. Aeternitas standing 1, holding a globe in $r$. hand and a sceptre in 1.

Variety not in Cohen, who gives this type only with obverse legend DIVA AVG FAvstina : see rst ed. ii, p. 424 , no. 13 .

133. Obv. as no. r $3 \mathrm{r}$.

Rev. avgy sta. Venus standing 1 , holding apple in $r$. hand and resting 1 . hand on a shield.

Cohen, ii, p. 4r9, no. 73 .

134. Obv. as no. $13 \mathrm{I}$.

Rev. Avgv STA. Ceres standing 1, holding two ears of corn in $r$. hand and lighted flambeau in 1 .

Cohen gives at vol. ii, p. 420 , no. 78 , a similar type in which Ceres is veiled.

135. Obv. as no. I3I.

Rev. AVGv sta. Vesta veiled standing 1, holding torch in $\mathrm{r}$. hand and sceptre in 1 .

Cohen, ii, p. 42I, no. 96. Two specimens.

136. Obv. as no. I3 I.

Rev. Avg vsta. Vesta (or Ceres) standing 1 , holding flambeau in $\mathrm{r}$. hand and resting 1. hand on hip.

Cohen, ii, p. 42 I, no. I04.

137. Obv. as no. I3I.

Rev. avgv sta. Vesta or Pietas veiled standing 1 , holding in $r$. hand a patera over a lighted altar, and in her 1 . the palladium (?).

Cohen, ii, p. 422 , no. I 6.

138. Obv. as no. I 3 I.

Rev. CONSE cRatio. Vesta or Pietas veiled standing 1 , raising $r$. hand and holding torch in 1.

Cohen, Ist edition, ii, p. 430 , no. 68 : not in 2 nd edition.
I39-I51. Marcvs Avredivs (A.D. 140-I80).

Cos. I (A.D. I40-I44).

139. Obv. avrelivscae saravgpiffcos. Head r, bare.

Rev. PIETASavg. Cultellus, aspergillum, lecuthos, augur's staff and simpulum.

Cohen, Ist edition, ii, p. 474 , no. I 50 : not in 2nd edition.

I40. Obv. avrelivscae saravgriff. Head r, bare.

Rev. cos Desir. Marcus standing 1, holding olive-branch in r. hand and cornucopiae in 1 .

Cohen, iii, p. I2, no. เoo, A.D. 144 .

Cos. II (A.D. I45 OR I46).

I4I. Obv. as no. r4o.

Rev. cos Ir. Marcus as in no. 140.

Cohen, iii, p. r3, no. rı.

Trib. Рot. III, Cos. II (A.D. I49).

142. Obv. as no. 140.

Rev. TRPotIII cosir. Athena helmeted standing $r$, holding spear in $r$. hand and resting 1 . hand on a shield.

Cohen, iii, p. 62, no. 618.

Trib. Рот. xvir, Cos. III (A.D. I63).

143. Obv. impmantoninvsavg. Head r, laureate.

Rev. Provdeortrpxvircosiri. Providentia standing 1 , holding. globe in $\mathrm{r}$. hand and cornucopiae in 1 .

Cohen, iii, p. 53, no. 525. Two specimens.

Trib. Pot. xviri, Cos. ini (A.D. 164).

144. Obv. antoninvsavg armeniacvs. Head r, bare.

Rev. PMTRPXVIII IMPIICOsIII. Mars helmeted and clad in lorica and cloak, standing $r$, holding spear in $r$. hand and laying 1 . hand on a shield.

Cohen, iii, p. 48 , no. 468 .

Trib. Рот. xxiv, Cos. iri (A.D. I70).

145. Obv. mantoninvs avgtrpxxiIII. Head r, laureate.

Rev. cos III. Diana standing 1, holding arrow in $\mathrm{r}$. hand and bow in 1 .

Cohen, iii, p. I4, no. I30.

146. Obv. Mantoninvsavg trpxxiIII. Head r, laureate.

Rev. Felicitas avgcosir. Felicitas standing 1 , holding olive-branch in $\mathrm{r}$. hand and sceptre in 1 .

Cohen, iii, p. 20, no. I82.

Trib. Рot. xxv, Cos. in (A.D. I7I).

147. Obv. mantoninvs avgtrpxxv. Head r, laureate.

Rev. cos III. Roma wearing helmet and chiton, seated l. on a lorica, holding Victory in $r$. hand and spear in 1.

Cohen, iii, p. 14, no. 133 . Two specimens 
Trib. Рot. xxxi, Cos. III (A.D. I77).

148. Obv. mantoninvsavg germsarm. Head r, laureate.

Rev. TRPXxxirm pvincosinipp. Pax draped and diademed, standing 1 , holding in $r$. hand a lowered torch with which she fires a heap of arms, and in 1 . hand a cornucopiae ; in exergue Paxavg.

Cohen, iii, p. 46 , no. 440 .

Cos. iir, Pater Patriae (a.d. $176-180$ ).

I49. Obv. mantoni nvsavg. Head $\mathrm{r}$, laureate.

Rev. cos-III P P. Athena wearing helmet and chiton, standing 1, holding olivebranch in $r$. hand and laying 1 . hand on a shield, a spear rests on her 1 . arm.

Cohen, iii, p. r6, no. 143 .

I50. $\mathrm{Obv}$. as no. 149 .

Rev. cos III P P. Salus seated 1, holding out $r$. hand and resting 1 . arm on back of seat, before her on the ground a serpent.

Cohen gives this reverse only with a bust of Marcus, laureate, draped and cuirassed on the obverse (vol. iii, p. I6, no. I 52.)

\section{Commemorative Coin.}

I5I. Obv. Divvsman toninvspivs. Head r, bare.

Rev. consecratio. Eagle standing 1 . on altar, head turned to $\mathrm{r}$.

Cohen gives this type for sesterces (vol. iii, p. II, no. 87), but not for denarii.

Two undeciphered.

I52-155. Favstina Junior (wife of Marcus Aurelius, d. 175).

Temp. Antoninvs Pivs.

152. Obv. favstinaavg pitavgril. Bust r, draped.

Rev. CONCOR DIA. Concordia seated 1. in chair of which the arms are cornucopiae, holding flower in her $r$. hand and resting l. arm on the arm of the chair.

Cohen, iii, p. 140 , no. 54 .

\section{Temp. Marcys Avrelivs.}

153. Obv. Favstina avgvsta. Bust r, draped. Rev. FECVN DITAS. Fecunditas standing $r$, holding sceptre in $r$. hand and a child on her 1 . arm.

Cohen, iii, p. 144, no. 99.

154. Obv. as no. 153; Faustina wears a pearl diadem.

Rev. Iv No. Juno veiled standing 1, holding a patera in $r$. hand and sceptre in 1 , on the ground before her is a peacock.

Cohen, iii, p. 146, no. 120; Cohen gives the diadem for bronze coins of this type, but omits it in his description of the aureus and denarius.

I55. Obv. as no. I54.

Rev. venvsGenetrix. Venus standing 1, holding a Victory in her r. hand and laying her 1 . on a shield which rests on a helmet; two figures are embossed on the shield.

Cohen, iii, p. 160 , no. 280 .
I 56-I 57. Lvcivs Vervs (A.D. I6 -I69).

Trib. Рот. Iv, Cos. II (A.D. I64).

156. Obv. Lvervsavg armeniacvs. Head r, laureate.

Rev. TRPIIII IMPIICOSII. Mars helmeted and wearing lorica standing $r$, holding spear in $r$. hand and laying 1 . hand on shield.

Cohen, iii, p. 192, no. 230.

Trib. Pot. vi, Cos. ir (A.D. I66).

I57. Obv. [lvervangarm] parthmax. Head r, laureate.

Rev. [TRPVIIMP] IIIICosir. Pax standing 1 , holding olive-branch in $r$. hand and cornucopiae in 1 ; in exergue pax.

Cohen, iii, p. 183 , no. 126.

\section{Lvcilla (wife of Lucius Verus).}

158. Obv. ivcilla avgvita. Bust r, draped.

Rev. conco RDIA. Concordia seated 1, holding patera in $\mathrm{r}$. hand and cornucopiae in 1 .

Cohen, iii, p. 215, no. 7 .

I59-165. Commodvs (A.D. 177-192).

Trib. Рot. vir, Cos. iII (A.D. I82).

159. Obv. mсомmodvs antoninvsavg. Head r, laureate.

Rev. LIBAVGVTRPVIIMPIIIICOSIIPP. Liberalitas standing 1 , holding tessera in $r$. hand and cornucopiae in 1 .

Cohen, iii, p. 269, no. 3 II.

Tris. Pot. $x$, Cos. iv (A.D. 185 ).

i6o. Obv. [сомm]Ant AVgPbrit. Head r, laureate.

Rev. PMTRPXIM pVII[cosmirmp]. Roma helmeted seated 1, holding a Victory in r. hand and cornucopiae in 1 ; in exergue roma.

Cohen, iii, p. 3r7, no. 66r.

$$
\text { Cos. V (A.D. I86-I9O). }
$$

I6r. Obv. MCOMMODVSan toninvsavg. Head r, laureate.

Rev. VICTBRIt cosvpr. Victoria seated $\mathrm{r}$. on heap of shields, holding a palm-branch in $r$. hand and supporting a shield on her 1 . knee.

Cohen records this design with the legend VICT BRIT in the exergue, on sesterces bearing inscriptions dated the 9 th, roth and I Ith years of tribunicia potestas, but does not give it for denarii, and the type seems new. It is probably to be assigned to the year of Commodus's 5 th consulship, which was also the I I th year of his tribunicia potestas, i.e. A.D. 186 . The coin is in poor condition but perfectly legible. 
Trib. Рот. xiII, Cos. v (A.D. I88).

162. Obv. мсомm-ANt P Felavgbrit. Head $r$, laureate.

Rev. PMTRPXIIIMPVIIICOsvpr. Salus seated $l$, feeding out of a patera a serpent entwined round an altar, l. elbow resting on the arm of her chair.

Cohen, iii, p. 302, no. 544 .

Trib. Рот. Xvir, Cos. vir (A.D. I92).

163. Obv. Lafilavrelcom mavgrfel. Head $r$, laureate.

Rev. PMTRPX VIIIMPVIIICOSVIIPP. Victoria ad'vancing to 1 , holding a wreath in $\mathrm{r}$. hand and palm-branch in 1 , to 1 . of figure a star.

Cohen, iii, p. 306 , no. 568 .

164. Obv. Laelavrelco mmavgpfel. Head r, laureate.

Rev. PMTRPXVIIIMPVIIICosvirpp. Felicitas standing 1 , holding in $\mathrm{r}$. hand a short caduceus and in l. a cornucopiae, to $l$. of figure a star.

Cohen, iii, p. 306, no. 57 I

165. Obv. LAelavrelcom MAvgPfel. Bust r. wearing lion-skin fastened at the neck.

Rev. Her CVI | RO MAN | AV Gv. in three lines; in the centre Hercules' club; the whole within a laurel-wreath.

Cohen, iii, p. 252, no. 190

One undeciphered.

\section{i66-186. Septimivs Severvis (A.D. 193-21 I)}

Cos. II, Imp. I-IV (A.D. I94).

166. Obv. IMPCAELSEPSEVPERTAVGCosir. Head $\mathbf{r}$, laureate.

Rev. BONA sPes. Spes advancing 1 , holding flower in $r$. hand and holding up skirt with 1 .

Cohen, iv, p. 9 , no. $5^{8}$.

167. $O b v$. as no. 166 .

Rev. BONIE v entvs. Bonus Eventus standing 1, holding up a basket of fruit in $r$. hand and two ears of grain in her l.

Cohen, iv, p. ro, no. 68.

168. Obv. IMPCAELSEPSEV PERTAVGCosir. Head $r$, laureate.

Rev. ForTVN R EDvc. Fortuna crowned with modius seated l, holding branch in $r$. hand and Amalthea's horn in 1.

Cohen, iv, p. 23 , no. I77.

i69. Obv. LSEPTSEVPe RTAVgimpin. Head r, laureate.

Rev. Libero patri. Bacchus nude except for a panther's skin thrown over head and shoulders, standing to 1 , holding a diota in $r$. hand and a thyrsus in l, before him a panther.

Cohen, iv, p. 34, no. 30 r.

Trib. Pot. III, Cos. II, Imp. IV-vil (A.D. I95). 170. Obv. as no. 168.

Rev. TRPIIIMPV cos.FI. Captive seated on the ground to $r$. with bowed head, before him a shield and arms.

Cohen, iv, p. 69, no. 66r.
171. Obv. LSEPTSEVPERT AVGIMPVII. Head $\mathrm{r}$, laureate.

Rev. pMtrpiII cosirpp. Athena helmeted standing $l$, holding in $\mathrm{r}$. hand a spear with point lowered, and carrying a round shield on her 1. shoulder.

Cohen, iv, p. 43, no. 391.

172. Obv. as no. $17 \mathrm{I}$.

Rev. [PMTRPIII] cosilpp. Mars helmeted, with mantle flying over shoulders, otherwise nude, advancing $r$, holding in $r$. hand a spear and carrying a trophy over 1 . shoulder.

Cohen, iv, p. 43 , no. 397 .

Trib. Pot. iv, Cos. il, Imp. viI-vin (A.d. 196). 173. Obv. LSEPTSEVPERT AVGIMPVIII. Head r, laureate.

Rev. PMTrPIIII cosilpp. Athena as in no. I7I.

Cohen, iv, p. 45 , no. 417.

174. Obv. as no. I73

Rev. BON Event. Bonus Eventus as in no. I67.

Cohen, iv, p. 10, no. 64, where the reverse inscription is given BONI EVENT: the letter I is not visible on this specimen.

175. Obv. as no. 173 .

Rev. SECVRItAs pvblica. Securitas seated 1. in high-backed chair, holding a globe in $r$. hand and resting $l$. fore-arm on arm of chair.

Cohen, iv, p. 68, no. 647. This coin and the preceding may belong to the early part of A.D. 197 .

Trib. Pot. v, Cos. II, Imp. vili-x (A.D. I97). 176. Obv. LSEPtSEVPert [AVGimp …]. Head r, laureate.

Rev. Hercvir [DEFENs]. Hercules standing facing, head turned to $r$, nude except for a lion-skin hung over l. shoulder, leaning on a club held in r. hand and holding a bow in 1 .

Cohen, iv, p. 26, no. 210 or 212.

Trib. Pot. vi, Cos. iI, Imp. x (A.d. I98).

177. Obv. Lseptsevpert avgimpx. Head r, laureate.

Rev. anno naeavgg. Annona standing 1, holding two ears of grain in $r$. hand and Amalthea's horn in 1 , her r. foot rests on the prow of a vessel.

Cohen, Ist edition, iii, p. 236 , no. 24 : in the 2 nd edition the reverse inscription is mistakenly given as ANNONAE AVG.

Imp. Xi, Parth. Max. (A.D. I 99 Or 200).

178. $O b v$. LSEPtsevavgimp xipartmax. Head $\mathbf{r}$, laureate.

Rev. VICTORIAE AVGGFEL. Victoria flying through the air to the $l, r$. hand extended, 1. arm bent; in front of her a round shield with central boss resting on a cippus.

Cohen, iv, p. 75 , no. 719. 
179. Obv. Lseptsevavgimpxipartmax. Head $\mathbf{r}$, laureate.

Rev. victPar T hicae. Victoria standing 1 , holding wreath in $r$. hand and carrying a trophy over l. shoulder; before her a Parthian captive seated on the ground.

Cohen, iv, p. 77, no. 741.

Prvs Avg. (A.D. 20I-2II).

180. Obv. Sevvervs pivsavg. Head r, laureate.

Rev. victpartmax. Victoria advancing to 1 , holding wreath in $r$. hand and palmbranch in 1 .

Cohen, iv, p. 73, no. 744, A.D. 201.

181. $O b v$. as no. 180 (?).

Rev. cos IIIPP. Victoria as in no. 180.

Cohen, iv, p. 14, no. 102, A.D. 202.

Trib. Рот. XIII, Cos. III (A.D. 205).

182. Obv. as no. 180 .

Rev. PMTRPXIIICOSIIIPP. Jupiter nude with mantle over shoulders, standing 1 holding thunderbolt in $\mathrm{r}$. hand and sceptre in 1, before him at his feet an eagle.

Cohen, iv, p. 49, no. 469 .

Trib. Рот. xiv, Cos. in (A.D. 206).

183. Obv. Severvisavg partmax. Head r, laureate.

Rev. pMTrpxiIII cosilipp. Annona standing 1 , holding two ears of grain in $\mathrm{r}$. hand and in 1. Amalthea's horn; before her on the ground a modius in which are two ears of grain.

Obverse and reverse dies belong to different issues, the former properly belonging to coins of the 7 th, 8th and 9 th years of tribunicia potestas, i.e. A.D. I99-20I : the obverse type in use in the 14 th year bears the legend severvs PIVs Avg as in Cohen, iv, p. 50 , no. 476 .

Trib. Рot. xvil, Cos. in (A.d. 209).

See no. 205 below.

Trib. Рот. xviII, Cos. ili (A.p. 2io).

184. Obv, as no. I80.

Rev. PMTRPXVIIICOSIIIPP. Jupiter with mantle hung over shoulders, otherwise nude, standing 1 , holding out a thunderbolt in his r. hand and a sceptre in 1 ; at his feet on either side of him a child.

Cohen, 1v, p. 57, no. 539 .

185. Obv. as no. 180 .

Rev. PONTIFTRP xiIIcos[IIIPP]. Female figure seated 1 , holding patera in $\mathrm{r}$. hand and double cornucopiae in 1 .

Hybrid coin. The reverse type was in use for coins of Caracalla minted in 210 ; see Cohen, iv, p. 194, nos. 483-4.

Forged CoIN.

186. Obv. as no. 180 .

Rev. PMTRPIII [CosIIPp] as no. 172 .

A forgery: the obverse type came into use only in the $9^{\text {th }}$ year of tribunicia potestas, A.D. 201 .

Two undeciphered.
187-195. Jvlia Domna (wife of Sept. Severus).

187. Obv. ivlia avgvita. Bust $r$, draped.

Rev. Conco R DIA. Concordia seated 1, holding patera in $\mathrm{r}$. hand and cornucopiae in 1 .

Cohen, iv, p. 108, no. 2r. Two specimens.

188. Obv. as no. 187 .

Rev. Diana rvcifera. Diana standing 1, holding in both hands a lighted flambeau; from her shoulders rise the two horns of a crescent.

Cohen, iv, p. 108, no. 27.

189. $O b v$. as no. 187 .

Rev. HIL A RITAs. Hilaritas standing 1, holding in $r$. hand a palm-branch of which the stem touches the ground, and in 1 . a sceptre.

Cohen, iv, p. I12, no. 76 .

I9o. $O b v$. as no. 187 .

Rev. Iv No. Juno veiled standing 1 , holding a patera in $r$. hand and sceptre in 1 , on the ground before her a peacock.

Cohen, iv, p. II3, no. 82 .

19i. Obv. as no. 187 .

Rev. IVNo Regina. Juno as in no. Igo.

Cohen, iv, p. II3, no. 97 .

192. Obv. as no. 187 .

Rev. piETAS avgG. Pietas veiled standing 1 , holding in $r$. hand a patera over a lighted and garlanded altar, and in 1 . an incensecasket.

Cohen, iv, p. I17, no. I50. Four specimens. 193. Obv. as no. 187 .

Rev. pietas pvblica. Pietas veiled, standing 1. and raising both hands in prayer; before her at her feet an altar.

Cohen, iv, p. I 18 , no. 156 .

194. Obv. as no. 187 .

Rev. Saecvil felicitas. Felicitas crowned with modius, standing $r$. in front of a vessel, of which the stern and rudder appears on her 1; she rests her 1 . foot on the prow of the vessel and supports a child on her knee with her 1 . hand, while with her r. she bares her 1 . breast.

Cohen, iv, p. 119, no. 174, but the design is imperfectly described : it recurs in gold as no. 177 where Cohen gives a more accurate description. Two specimens.

195. Obv. as no. 187.

Rev. [ves]TAE sanctae. Vesta veiled standing 1 , holding a patera in $r$. hand and sceptre in 1 .

Cohen, iv, p. 126 , no. 246 .

One undeciphered.

i 96-206. Caracalla (a.d. ig6-217).

Pontifex et Destinatvs Imperator (A.D. 197). 196. Obv. mavranto ninvscaes. Bust $r$, draped and bare-headed.

Rev. SEVERIAVGPIIFIL. Augur's staff, sacrificial knife, lecuthos, simpulum and sprinkler.

Cohen, iv, p. 204, no. 587. Two specimens. 
197. Obv. [MAvR]ANton CAFspontif. Bust $\mathrm{r}$, draped and bare-headed.

Rev. [Destinatormpe]rat. Augur's staff, flamen's cap, ox's head and simpulum.

Cohen, iv, p. 147 , no. 53 .

Trib. Pot. I or II (A.D. I98 or I99).

I97.* Obv. imp Caemavrantavgptrp[II ?]. Bust $r$, laureate and draped.

Rev. MINER victrix. Minerva standing 1 , holding a Victory in her $\mathrm{r}$. hand and a spear in 1, behind her is a trophy and before her a shield.

Cohen, iv, p. 161, no. $15^{8}$ or 162

Trib. Pot. iI (A.d. I99).

198. Obv. IMPCAEMAVRANTAVGPTRPIr. Bust r, laureate and draped.

Rev. SPESPV BLICA. Spes advancing 1, holding a flower in $r$. hand and catching up her skirt in 1 .

Cohen, iv, p. 206, no. 600 .

\section{Avgvstvs (A.D. 198-20I).}

199. Obv. ANTONINVs avgrstvs. Bust $r$, laureate and draped.

Rev. VIC TAE TERN. Victoria advancing to 1. with wings spread, holding a wreath in r. hand and palm-branch in 1 ; before her an oval shield on a cippus.

Cohen (iv, p. 207, no. 6i4) describes Victoria as holding a wreath in both hands. The palm-branch, though not very visible, can be seen on one of the Corbridge coins. Two specimens.

200. Obv. as no. I99.

Rev. mater Devm. Cybele wearing on her head a crescent, seated 1. in highbacked chair, resting her feet on a footstool and her l. elbow on a tympanum, holding a branch in her $r$. hand and a sceptre in her 1; behind her chair is a lion, and the head of a second lion is visible in front.

Hybrid coin, the reverse belonging properly to Julia Domna : see Cohen, iv, p. II 5 , no. I23, where the description of Cybele's head-dress as ' tourelée' needs correction.

Pivs Avgvstvs (A.D. 202).

20r. Obv. antoninvs pivsavg. Bust $r$, laureate and draped.

Rev. CONCORDIA FELIx. Plautilla and Caracalla standing and clasping hands.

Cohen, iv, p. I44, no. 23. Two specimens.

202. Obv. as no. 201 .

Rev. votasvs ceptax. Caracalla standing 1, holding in $\mathrm{r}$. hand a patera extended over an altar, and in 1 . hand a scroll.

Cohen, iv, p. 215, no. 688 .

Tris. Pot. viII, Cos. II (A.D. 205). See no. 2 II below.
Trib. Рот. Ix, Cos. II (A.D. 206).

203. Obv. as no. 201 .

Rev. PONTIFTRP virIIcosir. Mars wearing helmet, lorica and greaves, with mantle hung over his shoulders, standing 1 , resting his $\mathrm{r}$. hand on a shield and holding a spear in his 1 .

Cohen, iv, p. 187 , no. 424 .

Trib. Рот. $x$, Cos. il (A.D. 207).

204. Obv. antoninvs pivsavg. Head r, laureate.

Rev. PONTIFTRP xcosir. Mars as in no. 203 . Cohen, iv, p. 188 , no. 432 .

Tris. Pot. xi, Cos. iII (A.D. 208). See no. 212 below.

Trib. Pot. xII, Cos. III (A.D. 209).

205. Obv. as no. 201 .

Rev. PMTRPXVII cosIIIPP. Jupiter as in no. 184 .

Hybrid coin; the reverse die belongs to coins of Septimius Severus (Cohen, iv, p. 55, no. 525): the I7th year of tribunicia potestas of Sept. Severus equates with the I2th of that of Caracalla.

Trib. Pot. XIII, Cos. III (A.D. 210). See no. 185 above.

Liberalitas viII (A.D. 2I3).

206. Obv. antoninvspivs avgGerm. Head r, laureate.

Rev. IIberalavgviri. Liberalitas standing 1 , holding tessera in r.hand and cornucopiae in 1 .

Cohen, iv, p. 158 , no. 135 .

Two undeciphered.

207-208. Plavtilla (w ife of Caracalla).

207. Obv. plavtilla avgvista. Bust $r$, draped.

Rev. CONCORDIAEAETernaE. Plautilla standing $\mathrm{r}$, clasping the hand of Caracalla who faces 1 .

Not in Cohen with this obverse, but see Eckhel, vii, p. 226.

208. Obv. as no. 207.

Rev. venvsvictrix. Venus standing 1, holding an apple in $r$. hand and palmbranch in 1 , and resting 1 . fore-arm on a shield; before her stands Cupid.

Cohen, iv, p. 248 , no. 25 .

209-213. Geta (A.D. I98-212).

Caesar, Pontifex (a.D. 198-204).

209. Obv. Lseptimivsgetacaes. Bust $\mathrm{r}$, draped, bare-headed.

Rev. FELICIT AS T EMPOR. Felicitas standing 1 , holding a caduceus with short stem in r. hand and Amalthea's horn in 1.

Cohen, iv, p. 258 , no. 44 .

210. Obv. PSEPTGETA CAespont. Bust $\mathrm{r}$, draped and cuirassed, bare-headed.

Rev. Felicitas pvblica. Felicitas as in no. 209.

Cohen, iv, p. 257 , no. 38 . 


\section{HyBRID CoINS.}

2II. Obv. Getacaes Pontif. Bust r, draped, bare-headed.

Rev. PONTIFTRP viricosir. Mars nude but helmeted, standing 1 . with $r$. foot on a helmet, holding a branch in $r$. hand and spear in 1 .

The reverse is appropriate, to coins of Caracalla issued in A.D. 205 ; see Cohen, iv, p. 187 , no. 420 .

2I2. Obv. as no. 209 .

Rev. Pontiftrp xicosili. Mars armed and helmeted, advancing to $r$, holding in r. hand a sloping spear and on 1. arm a shield.

The reverse design belongs to the coinage of Caracalla for the year 208 : see Cohen, iv, p. rgo, no. 447 .

Trib. POt. II, Cos. II (A.D 2IO).

213. Obv. Impcaespsept getapivsayg. Head r, bearded and laureate.

Rev. Pontiftrpircosir. Genius standing 1, in front of him a lighted altar.

One undeciphered.

214-219. Elagabalvs (A.D. 218-222).

214. Obv. impcaesantoninvsayg. Bust, laureate, draped and cuirassed $r$.

Rev. victoranto NINIAVG. Victoria advancing rapidly to $\mathrm{r}$, holding up a wreath in $r$. hand and carrying a palm-branch over 1 . shoulder.

Cohen, iv, p. 35 I, no. 293, A.D. 218 (?).

215. Obv. IMPANTONINvsavg. Bust, laureate, draped and cuirassed $r$.

Rev. Temporvm Felicitas. Felicitas wearing on her head a head-piece in the form of a sphinx, holding in her $r$. hand a caduceus and in her 1. a cornucopiae.

Cohen, iv, p. 350 , no. 282, A.D. 219 (?).

Trib. Pot. iv, Cos. iII (A.D. 22I).

2I6. Obv. Impantoninvspivsavg. Head r, laureate.

Rev. PMTRPIIICOSIIIPP. Sun-god, nude, his head radiate, a mantle flying over his shoulders, advancing 1 , raising his r. hand and holding a whip in his 1 ; on the 1 . of the figure is a star.

Cohen, ist edition, iii, p. 526, no. 91 ; in the and edition (iv, p. 34r, no. 184) there is an error in the inscription.

217. Obv. as no. 215 (?).

Rev. PMtrpiricosiripp. Sun-god, nude, standing facing, with head turned to $r$ raising $r$. hand and holding whip in 1 .

Cohen, rst edition, iii, p. 526, no. 90 (correct); 2nd ed. iv, p. 341, no. 182 (incorrect).

218. Obv. IMPANTONINVs PIVSAyg. Bust r, draped and laureate, a horn rising from his head.

Rev. INvictrvsa cerdosavg. Elagabalus, horned, standing 1 , holding a patera in $r$. hand and club in 1 ; before him is a lighted altar, behind which lies an ox; a star in the field on the 1 .

Cohen, iv, p. 330 , no. $6 \mathrm{r}$.
Trib. Pot. v, Cos. III (A.D. 222).

2I9. $O b v$. as no. 218 .

Rev. PMTRPV cosiripP. Elagabalus standing

1 , holding in $r$. hand a patera extended over a lighted altar, and in 1. a cypressbranch; on his left, in field, a star.

Cohen, iv, p. 344, no. 2 I 3 .

One undeciphered.

Jvlia Pavla (first wife of Elagabalus).

220. Obv. IVliapavlaAvg. Bust r, draped.

Rev. Venvsge Netrix. Venus seated 1, holding apple in $r$. hand and sceptre in 1 .

Cohen, iv, p. $37^{8}$, no. 21, A.D. 219 or 220.

Jvlia Aqvilia (second wife of Elagabalus). 221. Obv. IVliaAqvilia severaAvg. Bust r, draped.

Rev. Concordia. Concordia standing 1 , holding patera in $r$. hand and double cornucopiae in 1 , before her an altar.

Cohen, iv, p. 380 , no. 2 , A.D. 220 or 221 .

222-223. Jvila Soaemias (mother of Elagabalus). 222. Obv. ivliasoaemiasavg. Bust $r$, draped.

Rev. venvscaelestis. Venus standing 1 , holding apple in $\mathrm{r}$. hand and sceptre in 1 .

Cohen, iv, p. 388 , no. 8 .

223. Obv. as no. 222.

Rev. venvscaelestis. Venus diademed seated 1 , holding apple in $r$. hand and sceptre in 1 ; before her stands a child.

Cohen, iv, p. 389 , no. 14 .

224-226. Jvila Maesa (grandmother of Elagabalus).

224. Obv. Ivliamaesaavg. Bust $r$, draped.

Rev. PIETA savg. Pietas veiled standing 1 , holding in $r$. hand a patera over a lighted altar, and in 1 . an incense-casket.

Cohen, iv, p. 394 , no. 29.

225. Obv. as no. 224.

Rev. PvDI cITIA. Pudicitia seated 1 , raising r. hand and holding sceptre in 1.

Cohen, iv, p. 395 , no. 36 .

226. Obv. as no. 224.

Rev. [SAECVL]IFELICITAs. Felicitas standing 1 , holding in r. hand a patera over an altar, and in 1 . a caduceus.

Cohen, iv, p. 395 , no. 45 .

One undeciphered.

227-236. Severvs Al.exander (A.d. 22I-235).

Trib. Pot. I-III, Cos. I (A.D. 222-4).

227. Obv. Impcmavrsev[Alexandavg]. Bust r, laureate and draped.

Rev. [PMTRP] COSPP. Jupiter nude with mantle hung from his shoulders, standing 1 , holding thunderbolt in $r$. hand and sceptre in 1 .

Cp. Cohen, iv, p. 422, no. 204.

Trib. Рot. vi, Cos. II (A.D. 227)

228. Obv. as no. 227.

Rev. PMTRPyi cosirpp. Mars nude and helmeted, with mantle flying over his shoulders, advancing r, holding a spear aslant in $r$. hand and carrying in 1 . hand a trophy on his shoulder.

Cohen, iv, p. 432 , no. 305 . 
229. Obv. as no. 227.

Rev. PMTRPVI [cosirpp]. Annona standing 1, holding two ears of grain in r. hand and Amalthea's horn in 1; before her on the ground a modius in which are two ears of grain.

Cohen, iv, p. 432, no. 315 .

UNDATED (A.D. 222-227).

230. Obv. as no. 227 with head r.

Rev. Pax avg. Pax advancing to 1, holding up an olive-branch in $r$. hand and a sceptre in 1.

Cohen, iv, p. 420 , no. 187.

'T'rib. Pot, viri, Cos. ili (A.D. 229).

231. Obv. impsevale xandavg. Head r, laureate.

Rev. PMTRPVIII [COSI]IIPp. Mars in armour advancing $r$, carrying spear slanting in $r$. hand and in 1 . a trophy on his shoulder.

Cohen, iv, p. $43^{8}$, no 375 .

TRIb. Pot. IX. Cos. III (A.D. 230).

232. Obv. as no, 23I

Rev. 1'MTRPviII cosinpp. Sun-god, nude, with rayed head, standing 1 , raising $r$. hand and nolding whip in 1.

Cohen, iv, p. $44 \mathrm{I}$, no. 388 .

233. Obv. as no. $23 \mathrm{I}$.

Rev. VICTOR IAAVG. Victoria standing 1 , holding wreath in $r$. hand and palmbranch in 1 .

Cohen, iv, p. $45^{8}$, no. $55^{6}$

234. Obv. as no. 232.

Rev. victoria avgvsti. Victoria standing $r$, resting $r$. foot on a helmet and supporting on her knee with her l. hand an oval shield on which she has inscribed vot $x$.

Cohen, iv, p. 459 , no. 566 . Two specimens.

Pivs Avg. (A.D. 23I-235).

235. Obv. [IMPale] Xan[DER] Pivsavg. Bust $r$. laureate; a fold of drapery falls over 1. shoulder.

Rev. PRo[VIDE] N[TIaAvg]. Providentia standing 1 , holding two ears of grain in r. hand and cornucopiae in 1 ; before her on the ground is a modius.

Cohen, iv, p. 452 , no. 5 OI.

236. Obv. IMPaLEXANDERPIVSAvg. Bust $r$, draped and laureate.

Rev. SPEs P vblica. Spes advancing to 1 , holding a flower in $\mathrm{r}$. hand and catching up skirt in 1 .

Cohen, iv, p. 457 , no. 543. Two specimens. the obverse of one has been twice struck.

Five undeciphered.

Jvita Mamaea (mother of Alexander).

237. Obv. IVliama maeang. Bust r, draped and diademed.

Rev. IVNoay gvstae. Juno seated 1 , holding in $\mathrm{r}$. hand a flower and on 1. arm a baby in swaddling clothes.

Cohen, iv, p. 493 , no. 32 .

One undeciphered.
Maximinvs thrax (A.D. 235-238).

238. Obv. IMPMAXIMINVSPIVSAVG. Bust r, draped and laureate.

Rev. providentiang. : Providentia standing $\mathrm{l}$, holding in her $\mathrm{r}$. hand a wand with which she points to a globe at her feet, and in 1 . a cornucopiae.

Cohen, iv, p. 513 , no. 77 .

GoRdian III (A.D. 238-244).

239. Obv. IMPGoRdiaNVSPIVSFrLAVG. Bust r, draped and laureate.

Rev. PMTrpiII cospr. Emperor on horseback advancing 1 , raising $r$. hand and holding sceptre in 1 .

Cohen, v, p. 45 , no. 234 , A.D. 240.

\section{SILIQVAE.}

Constantivs iI (Avgvstvs, A.D. 337-36I).

240. Obv. Dnconstan tivspfavg. Bust $r$, diademed and clad in imperial mantle.

Rev. votis $|\mathrm{xxx}|$ MvLtis $\mid \mathrm{xxxx}$ within a laurel 'wreath.

Mint-mark LvG. Lyons mint.

Cohen, vii, p. 492, no. 341. Two specimens, A.D. 353 .

Jvilan (Avgvstvs, A.D. 360-363).

241. Obv. [DNClivlia] Nvsppavg. Bust $r$, diademed, slightly bearded and draped.

Rev. vot $|\mathrm{x}| \operatorname{MVLT} \mid \mathrm{xx}$ within a laurel wreath.

Mint-mark Lvg. Lyons mint.

Cohen, viii, p. 62, no. 148 (?).

Two undeciphered.

242-243. Valentinian I (A.D. 364-375)

242. Obv. DNVAlentini anvspfavg. Bust $r$, diademed and draped.

Rev. RESTITV TORREIP. Emperor standing $r$, holding in $r$. hand the labarum and in l. a globe on which stands a Victory holding a wreath in her $r$. hand.

Mint-mark sLvg. Lyons mint.

Cohen, viii, p. 89, no. 18 . Two specimens.

243. $O b v$. as no. 242; Valentinian wears the paludamentum.

Rev. vRbs roma. Roma seated 1, holding in $r$. hand a globe on which stands a Victory, and in l. a sceptre.

Mint-mark RQ. Rome mint.

Cohen, viii, p. 99, no. 8 r.

Valens (A.D. $364-378$ ).

244. Obv. Dnvalen spfavg. Bust $\mathrm{r}$, diademed and draped.

Rev. as no. 242 .

$$
\text { Mint-mark } \frac{\mathrm{OF}-\mathrm{II}^{*}}{\text { CoNST }} \text {. Arles mint. }
$$

Cohen, viii, p. 107, no. 28 .

Gratian (A.d. $367-383$ ).

245. Obv. Dngratia nvspfavg. Bust r, diademed and draped.

Rev. virtvsro manorvm. Emperor seated on throne, looking to 1 , holding an orb in r. hand and reversed spear in 1 .

Mint-mark not visible.

Cohen, viii, p. 133 , no. 56 